\title{
The Protein-Bound Carbohydrates of Seromucoid from Normal Human Serum
}

\author{
By R. Varma, G. A. Michos and R. S. Varma
}

Biochemistry Department, Warren State Hospital, Warren, Pennsylvania, U.S.A. and'

R. D. Brown, Jr.

Department of Food Science and Human Nutrition, University of Florida, Gainesville, Florida, U.S.A.

(Reccived March 17/October 26, 1982)

Summary: The neutral sugars and hexosamines in the seromucoid fraction of normal human serum were identified and determined simultaneously by gas-liquid chromatography of their aldononitrile acetates. Besides the sialic acid, normal seromucoid contained fucose, arabinose, mannosc, glucose, galactose, glucosamine and galactosamine. The presence of arabinose and glucose, not previously reported in scromucoid, as well as the other known carbohydrate components determined by GLC were confirmed from their fragmentation patterns in the electron impact mass spectra and chemical ionization spectra.

\section{Die Protein-gebundenen Kohlenhydrate von Seromucoid aus normalem Serum des Menschen}

Zusammenfassung: Die Neutralzucker und Hexosamine in der Seromucoidfraktion aus normalen Serum des Menschen wurden durch Gaschromatographie ihrer Aldononitrilacetate identifiziert und gleichzeitig bestimmt. Neben Neuraminsäure enthielt normales Seromucoid Fucose, Arabinose, Mannose, Glucose, Galaktose, Glucosamin und Galaktosamin. Das bisher nicht mitgeteilte Vorkommen von Arabinose und Glucose in Seromucoid als auch die anderen durch Gaschromatographie bestimmten Kohlenhydrat-Komponenten wurden durch ihre Fragmentierungsmuster im Elektronenstoß- und chemischen Ionisations-Massenspektrum bestätigt.

\section{Introduction}

Seromucoids are the carbohydrate-protein conjugates in serum, which are soluble in $0.6 \mathrm{~mol} / 1 \mathrm{per}$ chloric acid but are insoluble in phosphotungstic acid. These consist, predominantly, of the carbohydrate-rich glycoprotein fraction called the "acute phase reactants". These acute phase reactants are very labile to stress situations and are produced in increased quantitics in the liver parenchymal cells and are poured into the blood stream in infection, trauma and inflammatory, degenerative and neoplastic diseases (1). The response pattern of the increased biosynthesis of this heterogenous group of trauma-inducible glycoproteins may differ considerably in various clinical conditions and stresses. Thus, the glycoproteins in seromucoid fraction may appcar in blood in different extents in various types of injuries to the tissues. A part of the glycoproteins in the seromucoid fraction also arises from the intercellular matrix of the conncctive tissue (2), which itself is influenced by several physiological and pathological states, including tissue destruction, tissue proliferation, wound healing, cancer, etc. (3). Analyses of the seromucoids for diagnostic uses are commonly carried out by turbidimetric (4), immunological (5) and spectrophotometric (6) methods. The spectrophotometric methods are based upon the fact that the seromucoid fraction is glycoprotcin in nature and its levels have been measured as total protein or tyrosinc or as its protein-bound carbohydrate residucs 
measured as total fucose, total hexose, hexosamine or sialic acid (6-8). However, it has been found that the solubility of the various seromucoid fractions in perchloric acid and the protection of the perchloric acid-soluble fraction from coprecipitation with proteins in phosphotungstic acid depend upon the nature and amounts of the covalently-bound carbohydrate residues (9). Since the carbohydrate composition of the different seromucoid fractions is not the same, a complete analysis of the individual carbohydrate components could provide more useful information on the seromucoids. This paper describes the complete carbohydrate composition of the seromucoids isolated from normal human serum.

\section{Materials and Methods}

Materials

Serum was obtained from blood drawn from healthy, male, Caucasian hospital employees between the ages of 22-55 years. The sugars used as standards were purchased from Sigma Chemical Co., St. Louis, Missouri. The ion-exchange resins AG 1-X2 ( $\mathrm{Cl}^{-}$form, 200-400 mesh) and AG 50W-X8 $\left(\mathrm{H}^{+}, 100-200\right.$ mesh) were obtained from BioRad Laboratories, Richmond, California. The anion-exchange resin $\mathrm{AG} 1-\mathrm{X}_{2}$ ( $\mathrm{HCO}_{3}^{-}$form) was prepared from AG 1-X2 ( $\mathrm{Cl}^{-}$form) by packing this resin in a column and sequentially washing with $2 \mathrm{~mol} / \mathrm{l}$ sodium hydroxide, distilled water, $22 \mathrm{~mol} / \mathrm{l}$ sodium hydrogen carbonate and distilled water. The acetylating kit containing pyridine and acetic anhydride was supplied by Applied Science Laboratories, State College, Pennsylvania. Inositol used as the internal standard was purchased from Difco Laboratories, Detroit, Michigan.

\section{Precipitation of seromucoid}

To $2.5 \mathrm{ml}$ of serum, contained in a $50 \mathrm{ml}$ centrifuge tube, $22.5 \mathrm{ml}$ of $8.5 \mathrm{~g} / \mathrm{l}$ sodium chloride solution were added. After a slow addition of $12.5 \mathrm{ml}$ of $1.8 \mathrm{~mol} / \mathrm{l}$ perchloric acid with intermittent shaking and waiting for 10 minutes, the mixtures was filtered through a Whatman No. 50 filter paper. To $25 \mathrm{ml}$ of this filtrate, $5 \mathrm{ml}$ of a $50 \mathrm{~g} / \mathrm{l}$ phosphotungstic acid solution were added. Following mixing by vortexing and after 10 minutes, the seromucoid precipitate was collected by centrifugation for 10 minutes at $4{ }^{\circ} \mathrm{C}$ and $2000 \mathrm{~min}^{-1}$. The precipitate was dried in a vacuum oven at room temperature and dissolved in $0.25 \mathrm{ml}$ of distilled water and reprecipitated with $1 \mathrm{ml}$ of $950 \mathrm{ml} / \mathrm{l}$ ethanol. The precipitate was transferred quantitatively into a $10 \mathrm{ml}$ glass ampoule with $3 \mathrm{ml}$ of $950 \mathrm{ml} / \mathrm{l}$ ethanol, using $1 \mathrm{ml}$ aliquots. The mixture in the ampoule was vortexed and centrifuged at $2000 \mathrm{~min}^{-1}$ for 10 minutes. After removing the supernatent, the precipitate was washed two more times with $3 \mathrm{ml}$ of $950 \mathrm{ml} / \mathrm{l}$ ethanol to remove perchloric acid and any possible carbohydrate contaminants in seromucoid.

\section{Isolation of neutral and amino sugars}

It was carried out by the following steps:

(a) The precipitate in the ampoule was dissolved by adding $0.5 \mathrm{ml}$ of $0.1 \mathrm{~mol} / \mathrm{l} \mathrm{NaOH}$ and $1 \mathrm{ml}$ of distilled water and vortexing. To this solution $50 \mu \mathrm{l}$ of myoinositol (internal standard) solution $(0.2 \mathrm{~g} / \mathrm{l})$ and $0.15 \mathrm{ml}$ of conc. $\mathrm{HCl}$ were added and after deaeration with $\mathrm{N}_{2}$ for $5 \mathrm{~min}$, the ampoule was sealed tightly and placed in an oven at $100^{\circ} \mathrm{C}$ for 4 hours. (b) The ampoule was cooled to room temperature and after carefully breaking the tip, $0.2 \mathrm{ml}$ of a freshly prepared solution $(500 \mathrm{~g} /$ 1) of sodium nitrite was added. The ampoule was resealed keeping the flame away from its contents. Vortexing for 25-30 min completed the deamination of hexosamines (2-amino-2-deoxyhexoses) to anhydrosugars $(10,11)$.

(c) The tip of the ampoule was broken and the pH of its contents adjusted to 5-6 with a pinch of $\mathrm{AG} 1 \mathrm{X}=2$ ( $\mathrm{HCO}_{3}^{-}$resin).This solution was deionized by passing it through a tandem arrangement of two columns made from $10 \mathrm{ml}$ disposable glass pipettes. The upper column $(1 \times 4 \mathrm{~cm})$ was packed with $\mathrm{AG} 50 \mathrm{~W}-\mathrm{X} 8\left(\mathrm{H}^{+}\right.$, 100-200 mesh) resin and it drained into a lower $(1 \times 5 \mathrm{~cm}) \mathrm{co}-$ lumn packed with $A G 1 \times-2\left(\hat{H C O}_{\overline{3}}\right)$ resin. About $\overline{70}-\hat{7} 5 \mathrm{ml}$ of eluate and the water washings were collected and reduced to a $1-2 \mathrm{ml}$ volume in a rotary evaporator at room temperature. This solution was transferred quantitatively into a $10 \mathrm{ml}$ ampoule and the solution was lyophilized.

\section{Derivatization for gas chromatography}

The residue in the ampoule was dried for $10 \mathrm{~min}$. in a vacuum oven and the aldoses and the 2,5-anhydrosugars; formed by deamination of hexosamines (10), were converted into their aldononitrile acetates by heating with hydroxylamine hydrochloride (3-4 mg) and pyridine (5 drops), and later with acetic anhydride (15 drops) as described previously (11). The derivatized and washed. (12) residue was dissolved in $2 \hat{5} \mu \mathrm{l}$ of chloroform and $5 . \mu \mathrm{l}$ were injected into the gas chromatograph.

\section{Preparạtion of standards}

A $4 \mathrm{ml}$ standard solution was prepared, which contained $8 \mathrm{mg}$ of each of $L$-rhamnose ( $=8.8772 \mathrm{~m} \overline{\mathrm{g}} L$-rhamnose $\left.\cdot \mathrm{H}_{2} \mathrm{O}\right), L$-fucose, $L$-arabinose, $D$-xylose and $16 \mathrm{mg}$ of each of $D$-mannose, $D$-glucose, $D$-galactose as well as $D$-glucosamine and $D$-galactosamine (=19.2586 mg of their hydrochlorides). A $0.1 \mathrm{ml}$ aliquiot of this standarid solution was mixed with $100 \mu \mathrm{l}$ of myoinositol solution $(2 \mathrm{~g} / \mathrm{l})$ and freeze dried. It was subjected to the aforementioned steps (a)-(c) for isolation and derivatization üsed for the seromucoid sample. However, the various reagents used were: for deamination of hexosamines, sodium nitrite solution $(500 \mathrm{~g} / \mathrm{l}) 0.3 \mathrm{ml}$; for derivatization, hydroxylamine hydrochloride $12-14 \mathrm{mg}$, pyridine 15 drops and acetic añhydride 45 drops., The derivatized and washed (12) residue was dissolved in $0.5 \mathrm{ml}$ of chloroform and $5 \mu \mathrm{l}$ of this solution were used for gas chromatography.

\section{Gas chromatography}

- A series 1200 Varian Aerograph equipped with a flame ionization detector and a $3380 \mathrm{~A}$ Hewlett Packara computing integrator was used. A stainless steel column $(9 \mathrm{ft} . \times 1 / 8$ in., i. d.) packed with $3 \%$ poly (neopentylglycol succinàte) on Gas Chrom Q (100/120 mesh, Applied Science Labs., State College, $\mathrm{Pa}$.) was used. The injector and detector temperatures were $130^{\circ} \mathrm{C}$ and $230^{\circ} \mathrm{C}$, respectively. The column temperature was programmed $130-195^{\circ} \mathrm{C}$ at $1^{\circ} \mathrm{C} / \mathrm{min}$ and the carrier gas used was nitrogen at a flow rate of $45 \mathrm{ml} / \mathrm{min}$.

\section{Sialic acid analysis}

The $0.5 \mathrm{ml}$ samples of the sera were diluted with $4.5 \mathrm{ml}$ of $8.5 \mathrm{~g} / \mathrm{l}$ sodium chloride solution and $2.5 \mathrm{ml}$ of $1.8 \mathrm{~mol} / \mathrm{l}$ perchloric acid were added with shaking. After $10 \mathrm{~min}$, the supernatant was centrifuged off and $1.0 \mathrm{ml}$ of $50 \mathrm{~g} / \mathrm{l}$ phosphotungstic acid was added to this supernatant. After shaking and allowing to stand for $\mathbf{1 0}$ min, cerntrifugation, inverting the centrifuge tube for a while, the precipitate was dissolved in $0.33 \mathrm{ml}$ of $0.1 \mathrm{~mol} / \mathrm{l} \mathrm{NaOH}$. After dilution with $3 \mathrm{ml}$ of water, the sialic acid was determined in $1.0 \mathrm{ml}$ of this solution using the diphenylamine reaction (6). 
Electron impact-chemical ionization mass spectrometry

These analyses were carried out in the Food Science and Human Nutrition Department of the University of Florida. Both the electron impact and chemical ionization spectra were recorded on a Finnigan Model 4021 instrument, which includes a data system. The gas chromatograph was fitted with a glass column (Finnigan $9610,6 \mathrm{ft} \times 2 \mathrm{~mm}$ i.d. $\times 4$ in) packed with $3 \%$ poly (neopentylglycol succinate) on Gas Chrom Q (100/120 mesh, Applied Science Laboratories, State College, $\mathrm{Pa}$.). The aldononitrile acetates of the neutral sugars and 2,5-anhydrohexoses (from deamination of hexosamines) were eluted isothermally at $215^{\circ} \mathrm{C}$ with helium as the carrier gas at a flow rate of $20 \mathrm{ml} / \mathrm{min}$. In the electron impact mode, the instrument was operated at an inlet temperature of $225^{\circ} \mathrm{C}$, an ionization potential of $70 \mathrm{eV}$ and an ion source temperature of $300^{\circ} \mathrm{C}$. For analysis by the quadropole mass spectrometer in the chemical ionization mode, the method of $\mathrm{Li}$ et al. (13) was slightly modified. In the chemical ionization mode, the instrument was operated at a source temperature of $150^{\circ} \mathrm{C}$, and ionization potential of $55 \mathrm{eV}$, a filament emission current of $0.3 \mathrm{~mA}$, an accelerating voltage of $-4 \mathrm{~V}$, and the isobutane reagent gas pressure of $5 \times 10^{-5}$ torr. About 1100 spectra were recorded for analysis and comparison during a typical 90 minute isothermal chromatographic separation.

\section{Results and Discussion}

The GLC of the aldononitrile acetates of the neutral sugars and the 2,5-anhydrohexoses formed from deamination of the hexosamines in the hydrolyzates of the normal human seromucoids showed the presence of fucose, arabinose, mannose, glucose, galactose, glucosamine and galactosamine. Figure 1a

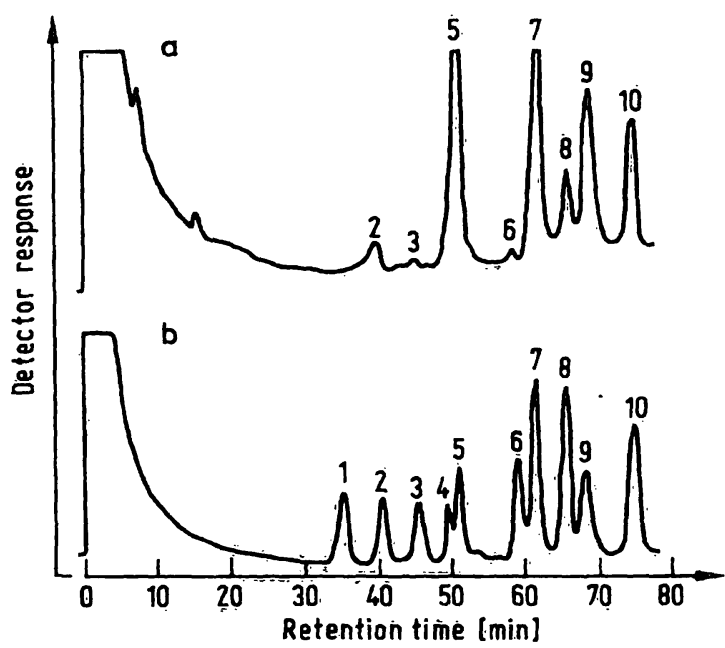

- Fig. 1. Gas chromatographic separation of aldononitrile acetates of neutral sugars and deaminated hexosamines.

a) standard mixture,

b) normal human seromucoid:

Peaks are:

1, rhamnose;

2, fucose;

3 , arabinose;

4, xylose;

5 , glucosamine;

7, mannose;

8, glucose;

9, galactose

10 , inositol. shows the GLC separation of the standard sugars. A typical chromatographic separation of the carbohydrate residues in the normal seromucoid hydrolyzates is shown in figure $1 \mathrm{~b}$. The quantitative values (mg/l) of these individual carbohydrate components, in terms of their ranges and mean \pm S.D., are given in table 1. The sialic acid contents of these seromucoids determined by spectrophotometry were 173.1 $\pm 27.4 \mathrm{mg} / \mathrm{l}$.

Tab. 1. Carbohydrate composition of seromucoid from 20 normal human subjects.

\begin{tabular}{lrr}
\hline Component & \multicolumn{1}{l}{$\begin{array}{l}\text { Range } \\
(\mathrm{mg} / \mathrm{l})\end{array}$} & $\begin{array}{r}\text { Levels (mg/l) } \\
\text { Mean } \pm \text { S.D. }\end{array}$ \\
\hline Fucose & $1.3-3.0$ & $2.0 \pm 0.1$ \\
Arabinose & $1.0-2.3$ & $1.6 \pm 0.3$ \\
Mannose & $9.1-27.0$ & $18.6 \pm 7.9$ \\
Glucose & $6.0-29.0$ & $16.9 \pm 9.3$ \\
Galactose & $12.1-53.0$ & $33.3 \pm 17.3$ \\
Glucosamine & $33.8-75.0$ & $58.1 \pm 16.4$ \\
Galactosamine & $1.3-4.4$ & $3.5 \pm 2.1$ \\
Sialic Acid & $148.0-209.0$ & $173.1 \pm 27.4$ \\
\hline
\end{tabular}

In addition to the chromatographic retention times, the electron impact and chemical ionization mass spectra provided evidence for the identities of arabinose and glucose, not mentioned in literature, as well as the previously reported carbohydrate residues: fucose, mannose, galactose, glucosamine and galactosamine in the hydrolyzates of normal human seromucoid. The electron impact mass spectra for arabinose and glucose gave typical spectra indicative of these sugars but the definitive parent mass ions were not present. Chemical ionization-mass spectrometry provided an unambiguous identification of arabinose and glucose in the sample. The spectra obtained at scan 240 (fig. $2 a$ ). clearly shows the $M+1$ species which is characteristic of peracetylated arabinonitrile to which a proton has been added. Although the scan 820 did not yield the $M+1$ ion for the glucose derivative, the presence of the expected large contributions from mass $\mathbf{3 2 8}$ was characteristic of glucose, as reported bỳ $L i$ et al. (13).

The mass chromatogram of figure 2 shows three peaks with substantial mass 256 contributions which is characteristic of pentoses. The mass chromatogram for mass ion 316 derived from peracetylated arabinonitrile shows a peak at scans $238-240$ (fig. 2c). The peak of mass 372 in scan 240 (fig. 2d) is due to reaction of the arabinose derivative with the isobutyl ion $\left(\mathrm{C}_{4} \mathrm{H}_{9}+\right)$. Thus the chemical ionization mass spectrum obtained at scan 240 (fig. 2a) confirms the presence of arabinose by three highly characteristic mass ions, i.e. 256, $316(\mathrm{M}+1)$, and 372 $(\mathrm{M}+57)$. 

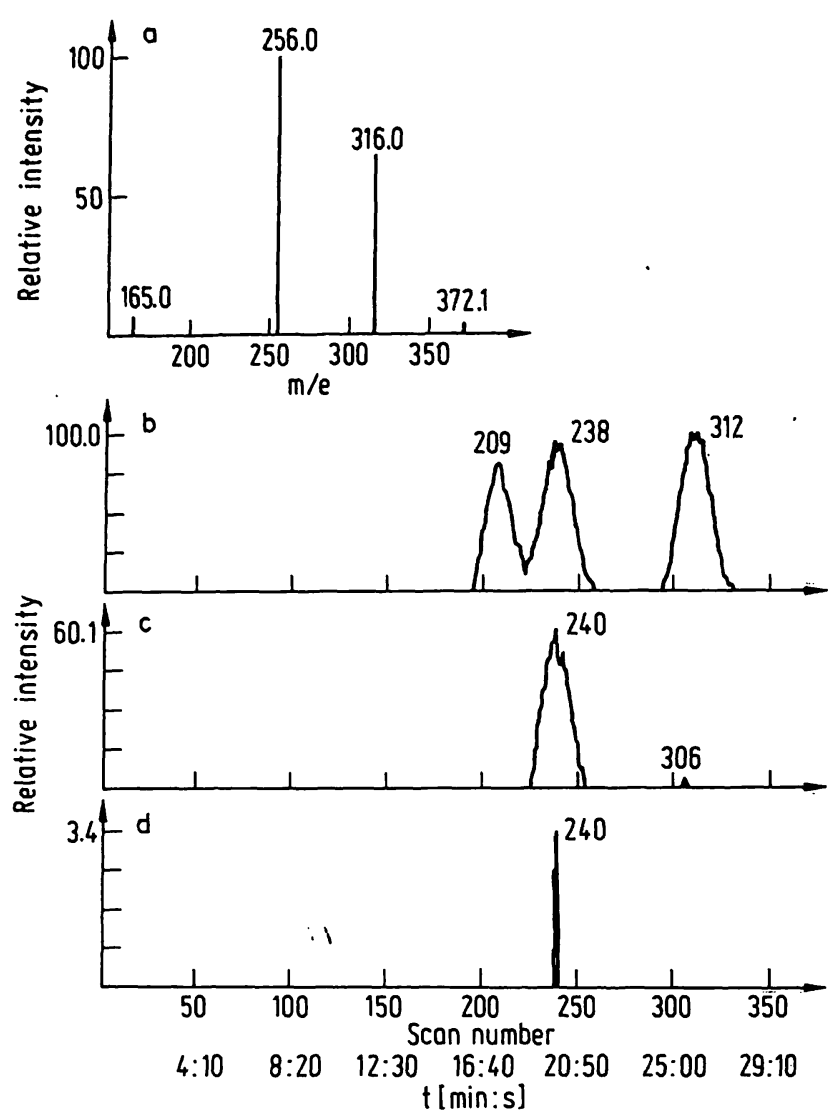

Fig. 2a-2d. Chemical ionization mass spectral identification of arabinose (see text). Figs. $2 \mathrm{~b}, 2 \mathrm{c}$, and $2 \mathrm{~d}$ represent scans of the mass fragments of 256,316 , and 372 $\mathrm{m} / \mathrm{e}$, respectively.

Seromucoids form only a small fraction of the serum glycoproteins but are comparatively richer in carbohydrates. These constitute a heterogenous mixture of the acute phase reactants, which include the $\alpha_{1}$-acid glycoprotein, $\alpha$-antitrypsin, haptoglobin, ceruloplasmin and haemopexin. Since the acute phase reactants originate in serum both from biosynthesis in liver (1) and the intercellular matrix of the tissues $(2,3)$, non-specific increases occur due to an enhanced hepatic synthesis in inflammatory and proliferative conditions as well as increased tissue breakdown in fever and in other pathological states. The amounts and types of seromucoids elevated, however, may vary in tissue destruction, proliferation or inflammation (1). Also, these levels would be affected by glomerular filtration and tubular reabsorption (14) and would, therefore, be altered in renal conditions. The seromucoid levels would be the net result of their synthesis in liver and their removal from blood into urine. Thus, decreased seromucoid levels (measured as protein-bound hexose) have been observed in diffuse parenchymatous liver diseases like cirrhosis due to decreased synthesis and also in nephrotic syndrome due to increased elimination of seromucoids in urine (6).
The seromucoid levels in sera are related to the serum glycoprotein fractions affected in disease, which in turn would be related to the carbohydrate composition of the affected fractions (9). In general, the higher the carbohydrate contents of these fractions, the higher is their solubility in perchloric acid and the higher would be the quantities of seromucoid recovered in the phosphotungstate precipitate (15). Not only the amount of the carbohydrate residues but also the nature of these residues in the seromucoid fractions influences the quantity of the precipitable seromucoid. For an example, the removal of sialic acid with the enzyme neuraminidase (EC 3.2.1.18) decreases the quantity of seromucoid precipitated with phosphotungstate (15). Thus, measurements of the individual components of neutral sugars, hexosamines and sialic acid would give a better picture of the seromucoid changes for diagnosis and prognosis of a disease process than just the measurement of the total precipitable material or a measurement of total fucose or sialic acid or total hexose or tyrosine contents of the seromucoid.

The precision of the analysis of the carbohydrate components of normal human seromucoid was determined by analyzing the same pool of the human seromucoid six different times. Table 2 gives the means, S.D.s, and the coefficients of variations (C.V.s) for the individual carbohydrate components. Low C.V.s suggest a high precision of the analyses.

Tab. 2. Estimation of precision of analysis of carbohydrate componerits in normal human seromuçọid pool $(n=6)$.

\begin{tabular}{lrll}
\hline Component & $\begin{array}{c}\text { Mean } \\
(\mathrm{mg} / \mathrm{l})\end{array}$ & S.D. & $\begin{array}{l}\text { C.V. } \\
(\%)\end{array}$ \\
\hline Fucose & 2.6 & 0.1 & 5.49 \\
Arabinose & 2.0 & 0.06 & 3.02 \\
Mannose & 19.9 & 0.8 & 4.35 \\
Glucose & 5.1 & 0.3 & 6.25 \\
Galactose & 29.6 & 1.2 & 4.05 \\
Glucosamine & 58.8 & 3.0 & 5.14 \\
Galactosamine & 1.3 & 0.1 & 8.50 \\
Sialic acid & 165.9 & 4.6 & 2.78 \\
\hline
\end{tabular}

The seromucoid is heterogenous electrophoretically and immuno-electrophoretically (16). It consists largely of the $\alpha_{1}$-acid glycoprotein (orosomucoid), which in human blood has been found by direct isolation methods to be present at a concentration of $0.2-0.4 \mathrm{~g} / \mathrm{l}(17)$ and at $0.91 \mathrm{~g} / \mathrm{l}$ by Mancini's immunochemical method (18). Although several fractions other than the $\alpha_{1}$-acid glycoprotein are also present in seromucoid in smaller amounts, the majority of the physical, biological and chemical studies have been concentrated on the former fraction isolated 
from human and animal sera. Analyses of the $\alpha_{1}$-acid glycoprotein by several investigators have shown a wide range in the carbohydrate composition and no pentose has been reported as its component (18). Also, although glucose has been detected in serum glycoproteins using G.L.C. (19) and mass-spectrometry (20), no glucose has been determined in the purified $\alpha_{1}$-acid glycoprotein. The lack of arabinose and glucose in the $\alpha_{1}$-acid glycoprotein may indicate that these sugar residues are probably present in some minor fraction/s other than the $\alpha_{1}$-acid glycoprotein fraction of the human seromucoid.

The presence of the pentose, arabinose, reported by different investigators in hyaluronic acid preparations from different mammalian sources has been reviewed elsewhere (21). Earlier reports on the presence of arabinose as a component of bovine brain hyaluronic acid were contested (22) and later its presence was established (23) upon confirmation by chromatographic, enzymatic and mass-spectrometric and chemical-ionization methods. Recently, Longas \& Meyer (24) using sequential hydrolysis of the rooster comb hyaluronic acid with a mixture of glycosidases detected only $<0.02 \%$ neutral sugars in the hydrolyzate. This surprisingly low neutral sugar content, as compared to the contents reported by other investigators in hyaluronates from other tissue sources, is difficult to explain. It may be attributable to the method of preparation of the rooster comb hyaluronate or to this tissue source being different from those used by other investigators.

The immunological studies have been reported only on the $\alpha_{1}$-acid glycoprotein fraction of seromucoid. This seromucoid fraction is weekly antigenic when injected in chickens and rabbits (17) and it gives a single, well-defined precipitin line on immunoelectrophoresis $(16,25)$. However, its electrophoresis at pH 5 resolves it into two variants, which are immunochemically identical (26). The antigenic property of this seromucoid fraction resides only in the protein part and not in its carbohydrate chain, since periodate oxidation destroys the carbohydrate residues without affecting its antigenicity $(16,17)$.

\section{Acknowledgements}

The authors wish to acknowledge the skilled assistance of $\mathrm{Mr}$. Charles du Mee of the Food Science and Human Nutrition Department in preparing columns and standards for gas chromatography. The authors' appreciation for the gas chromatographymass spectrometry is extended to Mr. J. L. Templeton at the Mass Spectrometry Facility of the Institute of Food and Agricultural Sciences of the University of Florida, Gainesville, Florida. The authors thank Mr. Carl Wolf for the photographic work.

\section{References}

1. Koj, A. (1974) in: Structure and Function of Plasma Proteins (Allison, A. C.. ed.), Vol 1, pp. 73-125, Plenum Press, London.

2. Mancini, R. E. (1963) Int. Rev. Cytol. 14, 193-222.

3. Varma, R. \& Varma, R. S. (1983) Mucopolysaccharides (Glycosaminoglycans) of Body Fluids in Health and Disease, de Gruyter, Berlin/New York.

4. de la Huerga, J., Dubin, A., Kushner, D. S., Dyniewicz, H. A. \& Popper, H. (1965) J. Lab. Clin. Med. 47, 403-408.

5. Ritchie, R. F. (1979) in: Immunoassays in Clinical Laboratory (Nakamura, R. M., Dito, W. R. \& Tucker, E. S., eds.), pp. 227-242, Alan R. Liss, New York.

6. Winzler, R. J. (1955) Methods Biochem. Anal. 2, 279-311.

7. Cannon, D. C., Olitzky, I. \& Inkpen, J. A. (1974) in: Clinical Chemistry: Principles and Technics (Henry, R. J., Cannon, D. C. \& Winkelman, J. W., eds:) 2nd. ed., pp. 465-470, Harper and Row, Hagerstown.

8. Shetlar, M. R. (1966) Progr. Clin. Pathol. 1, 419-457.

9. Winzler, R. J. (1971) in: Glycoproteins in Blood Cells and Plasma (Jamieson, J. A. \& Greenwalt, T. J., eds.) pp. 204-218, Lippincott, Philadelphia.

10. Varma, R. S., Varma, R., Allen, W. S. \& Wardi, A. H. (1974) J. Chromatogr. 93, 221-228.

11. Varma, R. \& Varma, R. S. (1976) J. Chromatogr. 128, 45-52.

12. Varma, R. \& Varma, R. S. (1977) J. Chromatogr. 139, 303-310.

13. Li, B. W., Cochran, T. W. \& Vercellotti, J. R. (1977) Carbohydr. Res. 59, 567-570.

14. Pironneau, F., Sternberg, M., Moisy, M., Feret, J., Rebeyrotte, P., Lagrue, G. \& Jayle, M.-F. (1974) Nephron 13, 434-442.
15. Anderson, A. J. (1965) Nature (London) 208, 491-492.

16. Schultze, H. E. \& Heremans, J. F. (1966) Molecular Biology of Human Proteins, Vol. I, American Elsevier, New York.

17. Jeanloz, R. W. (1966) in: Glycoproteins, BBA Library Vol. 5 (Gottschalk, A., ed.) pp. 362-394, Elsevier, Amsterdam.

18. Schmid, K. (1975) in: The Plasma Proteins: Structure, Function, Vol. I (Putnam, F. W., ed.) pp. 183-228, Academic Press, New York.

19. Gehrke, C. W., Waalas, T. P., Borek, E., Swartz, W. F., Cole, T. F., Kuo, K. C., Abeloff, M., Ettinger, D. S., Rosenshein, S. \& Young, R. C. (1979) J. Chromatogr., 162, 507-528.

20. Varma, R., Hoshino, A. Y. \& Vercellotti, J. R. (1980) Carbohydr. Res. 82, 343-351.

21. Varma, R., Varma, R. S., Allen, W. S. \& Wardi, A. H. (1975) Biochem. Exp. Biol. 11, 407-417.

22. Katzman, R. L. (1971) J. Neurochem. 18, 1187-1190.

23. Varma, R., Vercellotti, J. R. \& Varma, R. S. (1977) Biochim. Biophys. Acta 497, 608-614.

24. Longas, M. O. \& Meyer, K. (1981) Biochem. J. 197, $275-282$.

25. Heide, K. \& Haupt, H. (1964) Behringwerk-Mitt. (Behring Inst. Res. Commun.) 43, 161-193.

26. Yamauchi, T., Makino, M. \& Yamashina, I. (1968) J. Biochem. (Tokyo) 64, 683.

\author{
Dr. R. Varma \\ Director \\ Biochemistry Dept. \\ Warren State Hospital \\ P.O.Box 249 \\ Warren, Pennsylvania 16365
}


